\title{
Variable liver fat concentration as a proxy for body fat mobilization postpartum has minor effects on insulin-induced changes in hepatic gene expression related to energy metabolism in dairy cows
}

\author{
C. Weber, ${ }^{*}$ C. T. Schäff, ${ }^{*}$ U. Kautzsch, ${ }^{*}$ S. Börner, ${ }^{*}$ S. Erdmann, ${ }^{*}$ R. M. Bruckmaier,† M. Röntgen,‡ \\ B. Kuhla, ${ }^{*}$ and H. M. Hammon ${ }^{* 1}$ \\ *Institute of Nutritional Physiology (“Oskar Kellner”), Leibniz Institute for Farm Animal Biology (FBN), Dummerstorf 18196, Germany \\ †Veterinary Physiology, Vetsuisse Faculty, University of Bern, 3001 Bern, Switzerland \\ fInstitute of Muscle Biology and Growth, Leibniz Institute for Farm Animal Biology (FBN), Dummerstorf 18196, Germany
}

\begin{abstract}
The liver plays a central role in adaptation for energy requirements around calving, and changes in the effects of insulin on hepatic energy metabolism contribute to metabolic adaptation in dairy cows. Hepatic insulin effects may depend on body fat mobilization. The objective of this study was to investigate the effects of insulin on the hepatic gene expression of enzymes involved in energy metabolism and factors related to nutrition partitioning in cows with high and low total liver fat concentration (LFC) after calving. Holstein cows were retrospectively grouped according to their LFC after calving as a proxy for body fat mobilization. Cows were classified as low (LLFC; LFC $<24 \%$ fat/ dry matter; $\mathrm{n}=9$ ) and high (HLFC; LFC $>24.4 \%$ fat/ dry matter; $\mathrm{n}=10$ ) fat-mobilizing after calving. Euglycemic-hyperinsulinemic clamps $[6 \mathrm{mU} /(\mathrm{kg} \times \mathrm{min})$ of insulin for $6 \mathrm{~h}$ ] were performed in wk 5 antepartum (ap) and wk 3 postpartum (pp). Before and at the end of the euglycemic-hyperinsulinemic clamps, liver biopsies were taken to measure the mRNA abundance of enzymes involved in carbohydrate and lipid metabolism, expression related to the somatotropic axis, and adrenergic and glucocorticoid receptors. The mRNA abundance of pyruvate carboxylase, cytosolic phosphoenolpyruvate carboxykinase (PEPCK; PCK1), acylCoA-dehydrogenase very long chain $(A C A D V L)$, and hydroxyl-methyl-glutaryl-CoA-synthase 1 increased, but the mRNA abundance of solute carrier family 2 (SLC2A2 and SLC2A4), growth hormone receptor 1A (GHR1A), insulin-like growth factor 1 (IGF1), sterol regulatory element binding factor 1 , adrenoceptor $\alpha$ $1 \mathrm{~A}$, and glucocorticoid receptor decreased from ap to pp. Insulin treatment was associated with decreased
\end{abstract}

Received August 1, 2016.

Accepted November 7, 2016.

${ }^{1}$ Corresponding author: hammon@fbn-dummerstorf.de
PCK1, mitochondrial PEPCK, glucose-6-phosphatase, propionyl-CoA-carboxylase $\alpha, \quad$ carnitine-palmitoyltransferase $1 \mathrm{~A}, A C A D V L$, and insulin receptor mRNA, but increased IGF1 and SLC2A 4 mRNA ap and pp and GHR1A mRNA pp. The mRNA abundance of SLC2A4 was greater, and the mRNA abundance of GHR1A and IGF1 tended to be lower in LLFC than in HLFC. Administration of insulin, albeit at a supraphysiological dose, was associated with inhibition of gene expression related to glucose production and $\beta$-oxidation, but we observed variable effects in the degree of insulin depression of individual genes. Insulin status is important for regulation of nutrient partitioning, but different LFC pp had very little influence on changes in hepatic gene expression following administration of insulin.

Key words: dairy cow, insulin, hepatic gene expression, energy metabolism, somatotropic axis

\section{INTRODUCTION}

During the transition from late pregnancy to lactation, marked changes occur in carbohydrate and lipid metabolism to ensure nutrient supply for milk production in high-yielding dairy cows (Bauman, 2000; Ingvartsen and Andersen, 2000; Drackley et al., 2001). Nutrient partitioning is under homeorhetic control, resulting in several endocrine changes during the transition period (Bauman, 2000; Ingvartsen and Andersen, 2000; Drackley et al., 2001). Insulin plays a pivotal role in energy partitioning during this period, and pancreatic insulin release and insulin sensitivity also change with the onset of lactation (McDowell, 1983; Brockman and Laarveld, 1986; De Koster and Opsomer, 2013). Insulin affects hepatic glucose and lipid metabolism and influences the gene expression of key enzymes of hepatic gluconeogenesis, fatty acid oxidation, ketogenesis, and cholesterol synthesis (Donkin, 1999; Nguyen et al., 2008; Loor, 2010). However, due to changes in insulin release and sensitivity around the time of calving, the 
effects of insulin on the gene expression of enzymes in the liver may depend on lactation stage (Sano et al., 1993; Hayirli, 2006; Aschenbach et al., 2010).

Insulin action in cows also depends on body condition, and impaired insulin sensitivity has been observed primarily in overconditioned dairy cows before and after calving (De Koster and Opsomer, 2013; De Koster et al., 2015). Lipid mobilization in early lactation varies greatly among individual cows (Hammon et al., 2009; Weber et al., 2013b); thus, the liver has to cope with a variable substrate flow for energy utilization. Interestingly, cows with elevated body condition and greater body fat mobilization during the transition period show greater body fat oxidation as measured by indirect calorimetry in a respiration chamber before calving, when body fat mobilization and an increase in the release of nonesterified fatty acids (NEFA) into the plasma is not occurring (Börner et al., 2013). We speculate that the regulation of hepatic energy metabolism by insulin may be involved in variable hepatic fuel oxidation.

In this study, we investigated insulin effects on hepatic energy metabolism using the euglycemic-hyperinsulinemic clamp (EGHIC) in dairy cows in late pregnancy and early lactation with high and low body fat mobilization indicated by their mean total liver fat concentration (LFC; Schäff et al., 2012). Investigations of the liver focused on 19 candidate genes involved in carbohydrate and lipid metabolism and on the regulation of energy partitioning by the somatotropic axis and adrenergic and glucocorticoid receptors. It is well known that changes in the hepatic somatotropic axis occur around the time of calving in dairy cows (Etherton and Bauman, 1998), and the adrenergic and glucocorticoid systems are known to counteract the effects of insulin (Mc Dowell, 1983; Brockman and Laarveld, 1986).

The dairy cows investigated in this study were grouped according to their mean total LFC postpartum (pp), which indicated differences in body fat mobilization around the time of calving in the present study (Schäff et al., 2012), as well as in previous studies (Hammon et al., 2009; Weber et al., 2013b). Performance data from the cows in wk 5 antepartum (ap) and wk $3 \mathrm{pp}$, as well as studies on insulin responsiveness, pancreatic insulin release, and postpartum insulin-dependent glucose metabolism around the time of calving, were recently published in a companion paper by Weber et al. (2016). The cows showed similar DMI, milk yield, and energy balance during the clamp studies, but they differed with respect to body condition and whole-body fuel oxidation (Börner et al., 2013; Weber et al., 2016).

Focusing on individual variation in the regulation of hepatic energy metabolism, the present study aimed to determine insulin-dependent differences in the hepatic gene expression of key enzymes involved in carbohydrate and lipid metabolism and factors related to nutrient partitioning in high-yield dairy cows that varied in their fat mobilization around the time of calving (Weber et al., 2016). Because the present study was based on a study of the measurement of maximal insulin response using the EGHIC (Weber et al., 2016), we used a supraphysiological insulin dose. We hypothesized that the regulation of gene expression with regard to hepatic carbohydrate and lipid metabolism, as well as nutrient partitioning by insulin, may vary before and after calving and with respect to elevated hepatic fat content. These findings will contribute to the understanding of the adaptation of hepatic energy metabolism and the effect of insulin on hepatic regulation in the livers of high-yield dairy cows.

\section{MATERIALS AND METHODS}

\section{Animals, Husbandry, and Feeding}

All treatments were conducted in accordance with the guidelines for the use of animals as experimental subjects of the State Government of MecklenburgWestern Pomerania (Registration No. LALLF M-V/ TSD/7221.3-2.1-021/09). For the present study, 20 multiparous German Holstein cows from a local farm were chosen based on their milk yield during their previous lactation (>10,000 kg/305 d) and age (second to fourth lactation). To minimize genetically based variations in fat metabolism, all cows were selected for heterozygosity at a polymorphic locus in the acyl-CoAdiacylglycerol acyltransferase 1 gene (DGAT1 K232A: lysine or alanine at position 232), which affects fat metabolism in muscle and the mammary glands (Thaller et al., 2003).

We focused our investigations on transcriptional response in the liver to insulin treatment using the EGHIC at wk 5 ap and wk $3 \mathrm{pp}$. These studies were embedded in a comprehensive project on energy metabolism and regulation of feed intake in dairy cows during the transition period. The results of the clamp studies on insulin-dependent glucose metabolism have recently been published by Weber et al. (2016). Dairy cows investigated in this study were observed from wk 7 ap until wk $5 \mathrm{pp}$; animal management and performance data have been published previously (Schäff et al., 2012; Börner et al., 2013). All cows were kept in a tie stall and fed a TMR (ad libitum, twice daily) adapted for the dry period (a far-off diet from wk 7 to wk 4 ap and a close-up diet from wk 3 ap until calving) or lactation. The ingredients and chemical compositions of the different diets were determined according to the recommendations of the German Society of Nutritional 
Physiology (GfE, 2001, 2008; Supplementary Table S1; https://doi.org/10.3168/jds.2016-11808).

Cows were grouped according to their mean total LFC on d 3, 18, and 30 after calving in low [LLFC; LFC $<24 \%$ (mean $20.0 \pm 2.0 \%$ ) total fat/DM liver tissue; $\mathrm{n}=9$ ] and high [HLFC; LFC $>24.4 \%$ (mean $30.2 \pm 1.8 \%$ ) total fat/DM liver tissue; $\mathrm{n}=10$ ] fatmobilizing cows. Due to severe illness during the trial, 1 LLFC cow was excluded from the sampling (Weber et al., 2016). Changes in liver fat concentration during the entire experimental period and on body condition at the time of the clamp studies have been reported by Schäff et al. (2012) and Weber et al. (2016).

\section{Euglycemic-Hyperinsulinemic Clamp Studies}

As described recently in a companion paper (Weber et al., 2016), EGHIC studies were carried out in wk 5 ap and wk 3 pp. The EGHIC was initiated after a $7-\mathrm{h}$ feed withdrawal, and blood sampling for the measurement of basal plasma concentrations of glucose, insulin, and NEFA. The bovine insulin (Hybri-Max; SigmaAldrich Chemie GmbH, Steinheim, Germany; activity $31 \mathrm{U} / \mathrm{mg}$ ) was infused at a constant rate of $6 \mathrm{mU} / \mathrm{kg}$ of BW per min for the next $6 \mathrm{~h}$, resulting in supraphysiological plasma insulin concentrations (Weber et al., 2016). Glucose infusion commenced 5 min after insulin infusion and was started at a rate of $4 \mathrm{~mL} / \mathrm{min}$ in a 40\% (wt/vol) glucose solution (B. Braun Melsungen AG, Melsungen, Germany). During the EGHIC study, plasma was sampled every $5 \mathrm{~min}$, and glucose concentration was analyzed immediately (1500 Sport YSI Lactate analyzer; Kreienbaum, Langenfeld, Germany). The glucose infusion rate was adjusted every 5 min to maintain the established basal plasma glucose concentration (Weber et al., 2016). The blood samples for measurement of insulin and NEFA were taken every 10 and $20 \mathrm{~min}$, respectively, and analyses for plasma concentrations of insulin and NEFA have been described recently (Weber et al., 2016).

\section{Liver Tissue Sampling and Analyses}

Liver tissue samples were taken by needle biopsy under local anesthesia on d 3,18, and $30 \mathrm{pp}$ to measure LFC (Weber et al., 2016) and in wk 5 ap and wk 3 pp (d 18) before and at the end of the EGHIC to measure the abundance of genes in the mRNA related to energy metabolism and regulation of nutrient partitioning. For biopsies before the clamp studies, we used a tailor-made needle (outer diameter $6 \mathrm{~mm}$ ) to get about $1 \mathrm{~g}$ liver tissue. After the clamp, we used a tailor-made needle (outer diameter $3 \mathrm{~mm}$ ) to obtain approximately 300 mg of liver tissue. For technical reasons, liver biopsies could not be taken in all cows before and at the end of the EGHIC. The number of liver samples amounted to 10 for HLFC before EGHIC and 8 and 7 at the end of EGHIC ap and pp, respectively. For LLFC, the number of liver samples was $9 \mathrm{ap} / 8 \mathrm{pp}$ before EGHIC and 7 ap $/ 5 \mathrm{pp}$ at the end of the EGHIC. After incision of the skin, liver tissue was harvested using a tailor-made biopsy needle (outer diameter $6 \mathrm{~mm}$ ). Tissue samples were immediately frozen in liquid nitrogen and stored at $-80^{\circ} \mathrm{C}$ until analysis. Frozen liver tissue was homogenized under liquid nitrogen for all analyses (Schäff et al., 2012).

The LFC was measured as total liver fat concentration and has recently been described (Weber et al., 2016). Using a FastPrep 120 centrifuge (Thermo Electron Corporation, Waltham, MA), $50 \mathrm{mg}$ of liver tissue powder were homogenized. Total RNA was extracted using TRIzol Reagent (Invitrogen, Carlsbad, $\mathrm{CA}$ ) according to the manufacturer's instructions (Hammon et al., 2009). The quality of the total RNA was confirmed by gel electrophoresis on agarose gel stained with ethidium bromide. Yields were detected by a spectrophotometer (NanoPhotometer; Implen, Munich, Germany), and concentrations determined by measuring optical density 260:280 $\mathrm{nm}$. The absorption ratio was between 1.7 and 2.2 for all samples (Schäff et al., 2012). Total RNA was transcribed into cDNA and purified as described previously (Hammon et al., 2003, 2009). Genes encoding for enzymes and transporters involved in carbohydrate metabolism were cytosolic and mitochondrial phosphoenolpyruvate carboxykinase (cytosolic PCK1, PEPCKc; mitochondrial PCK2, PEPCKm), pyruvate carboxylase $(\boldsymbol{P C}, \mathbf{P C})$, glucose6-phosphatase ( $G 6 P C$, G6Pase), propionyl-CoAcarboxylase a (PCCA, PCCA), solute carrier family 2, members 2 and 4 (SLC2A2, SLC2 A4, encoding for glucose transporters GLUT2 and GLUT4). Selected enzymes involved in hepatic fatty acid oxidation were carnitine-palmitoyl-transferase 1A (CPT1A, CPT), acyl-CoA-synthetase long chain 1 (ACSL1, ACSL), and acyl-CoA-dehydrogenase very long chain $(\boldsymbol{A C A D}$ $\boldsymbol{V L}$, ACADVL). The enzymes hydroxyl-methyl-glutaryl-CoA-synthase 1 and hydroxyl-methyl-glutaryl-CoAsynthase 2 (HMGCS1, HMGCS2) were quantified, because they regulate the cholesterol biosynthesis and ketogenesis, respectively. The transcription factor sterol regulatory element binding factor 1 (SREBF1) was measured because of its role in the regulation of lipid metabolism. In addition, factors involved in the somatotropic axis as growth hormone receptor 1A $(\boldsymbol{G H R} \mathbf{A})$, insulin-like growth factor 1 (IGF1), and insulin receptor $(\boldsymbol{I N S \boldsymbol { R } )}$ were investigated. Fur- 
thermore, mRNA abundances of adrenoceptors $\alpha 1 \mathrm{~A}$ and $\beta 2(\boldsymbol{A D R} \boldsymbol{A} \mathbf{1 A}, \boldsymbol{A D R B 2})$ and nuclear receptor subfamily 3 group C member 1 (NR3C1, also known as glucocorticoid receptor) in the liver were measured. Specific primer sequences were used as described in previous studies (Hammon et al., 2009; van Dorland et al., 2009; Graber et al., 2010, Gross et al., 2011; Schäff et al., 2014).

Quantification of mRNA abundance relative to reference genes in liver tissue was performed by real-time reverse-transcription PCR (LightCycler; Roche Applied Science, Mannheim, Germany) using SYBR Green I as the fluorescent dye according to Pfaffl (2001). Phosphoglycerate kinase 1 ( $\boldsymbol{P} \boldsymbol{G K} \mathbf{1})$ was used as the reference gene, because it was not affected by LFC, time around calving, or insulin infusion. This was not the case for $\beta$-actin and GAPDH, which were also tested for use as reference genes. After a PCR run, a melting point analysis for each PCR product was performed to verify the specificity of each product. Additionally, gel electrophoresis of the PCR product demonstrated only a single band of the expected size. Products were verified by sequencing using an ABI Sequencing kit (ABI Big Dye Terminator; Applied Biosystems, Darmstadt, Germany) and an ABI 310 Genetic Analyzer (Applied Biosystems). The values of the crossing point (quantification cycle; $\mathbf{C q}$ ) were corrected for different runs by an internal standard $(\Delta \mathrm{Cq})$. In addition, $\Delta \mathrm{Cq}_{\mathrm{PGK} 1}$ was used to normalize measurements of the target genes, as indicated by $\Delta \Delta \mathrm{CP}=\Delta \mathrm{Cq}_{\text {target }}-\Delta \mathrm{Cq}_{\mathrm{PGK} 1}$ (Hammon et al., 2009). The efficiency of the PCR was $>1.8$ and inter- and intra-assay CV for reverse-transcription PCR of target and reference genes were $<1 \%$ (Hammon et al., 2009; Weber et al., 2013a; Schäff et al., 2014).

\section{Statistical Analyses}

Statistical analyses were performed using SAS for Windows, version 9.4 (SAS Institute, Inc., 2013). Milk yield around the time of EGHIC, plasma concentrations, liver fat concentration, and gene expression in the liver were assessed by repeated measurements ANOVA using the MIXED procedure with an unstructured covariance matrix. The ANOVA model contained the fixed effects LFC (groups LLFC and HLFC), time (5 wk ap, 3 wk $\mathrm{pp}$ ), insulin treatment, and the interaction between LFC, time, and insulin treatment. It also contained the fixed effects running block of cows during the trial (block) and the technical replicate of the quantitative real-time PCR (run). Repeated measures on each animal were taken into account (repeated factor: cow). The least squares means (LSM) and standard error (SE) were computed for the fixed effects of LFC, time, insulin, and their respective interactions in the ANOVA model to display the results. All differences of these LSM were tested using the Tukey-Kramer procedure. Differences with $P<0.05$ were considered significant.

\section{RESULTS}

\section{Liver Fat Concentration and Plasma Concentrations of Glucose, Insulin, and Nonesterified Fatty Acids}

Liver fat content in LLFC cows ranged from 129 to $239 \mathrm{mg} / \mathrm{g}$ DM liver tissue (mean $\pm \mathrm{SE}: 195 \pm 0.1 \mathrm{mg} / \mathrm{g}$ $\mathrm{DM}$ ), and in HLFC cows, from 244 to $393 \mathrm{mg} / \mathrm{g} \mathrm{DM}$ (mean $\pm \mathrm{SE}: 306 \pm 0.2 \mathrm{mg} / \mathrm{g} \mathrm{DM}$ ); thus, the mean LFC (d 3, 18, $30 \mathrm{pp})$ differed significantly $(P<0.01)$ between groups, but LFC did not differ between groups before calving (Schäff et al., 2012; Weber et al., 2016). Body condition scores ranged from 3.0 to 4.8 (ap) and from 1.5 to 4.5 (pp) in HLFC and from 2.8 to 4.0 (ap) and 1.5 to 2.9 (pp) in LLFC. Data and statistical calculations have been published recently in a companion paper (Weber et al., 2016). Milk yield around the time of the clamp study did not differ between groups, but increased from $15.6 \pm 1.1 \mathrm{~kg}$ in the evening before the clamp to $18.7 \pm 1.1 \mathrm{~kg}$ in the evening after the clamp and then decreased to $17.9 \pm 1.1 \mathrm{~kg}$ in the evening of the day after the clamp (data are LSM $\pm \mathrm{SE}$ ).

Glucose concentrations in the basal plasma decreased $(P<0.01)$ from ap to $\mathrm{pp}$ in both groups, remained constant throughout the EGHIC, and did not differ between groups (LSM $\pm \mathrm{SE}$ for glucose concentration in both groups was $4.15 \pm 0.17 \mathrm{mmol} / \mathrm{L}$ ap and $3.63 \pm$ $0.18 \mathrm{mmol} / \mathrm{L} \mathrm{pp}$; Weber et al., 2016). Insulin concentrations in the basal plasma decreased $(P<0.01)$ in both groups from ap to pp and was higher $(P<0.05)$ ap in the HLFC cows than in the LLFC cows (LSM $\pm \mathrm{SE}$ for basal insulin concentration in the LLFC was 0.49 $\pm 0.09 \mu \mathrm{g} / \mathrm{L}$ ap and $0.19 \pm 0.10 \mu \mathrm{g} / \mathrm{L} \mathrm{pp}$, and in the HLFC was $0.90 \pm 0.09 \mu \mathrm{g} / \mathrm{L}$ ap and $0.19 \pm 0.11 \mu \mathrm{g} / \mathrm{L}$ pp). During the EGHIC steady state, insulin increased to $33.0 \pm 1.2 \mu \mathrm{g} / \mathrm{L}$ ap and $29.5 \pm 1.3 \mu \mathrm{g} / \mathrm{L} \mathrm{pp}$. The increase of insulin during the EGHIC was greater $(P$ $<0.01)$ ap than pp, but did not differ between groups (Weber et al., 2016). Basal plasma NEFA concentrations did not differ between groups, but were lower $(P$ $<0.01)$ ap $(295 \pm 61 \mu \mathrm{mol} / \mathrm{L})$ than pp $(905 \pm 65$ $\mu \mathrm{mol} / \mathrm{L})$. Plasma NEFA concentrations decreased $(P<$ 0.01) during the EGHIC steady state in both groups, and concentrations during the EGHIC steady state were lower ap $(55 \pm 34 \mu \mathrm{mol} / \mathrm{L})$ than pp $(219 \pm 36$ $\mu \mathrm{mol} / \mathrm{L}$; Weber et al., 2016). We observed no difference in the rates of NEFA decrease and glucose infusion during EGHIC between groups (Weber et al., 2016). 


\section{Genes Related to Hepatic Carbohydrate Metabolism}

The mRNA abundance of $P C$ increased $(P<0.01$, Figure 1A) considerably after calving and was similar between groups before and after calving (Figure 1A). The abundance of $P C K 1 \mathrm{mRNA}$ was higher after calving than before $(P<0.01$, Table 1$)$ and was strongly suppressed by insulin treatment $(P<0.001)$ ap and pp in both groups; the reduction of $P C K 1 \mathrm{mRNA}$ after insulin treatment was greater after calving (time $\times$ insulin: $P<0.05$; Figure 1B). The abundance of $P C K 2$ mRNA was similar between groups at all time points, but was suppressed by insulin treatment $(P<0.001$, Figure $1 \mathrm{C})$. The mRNA encoding for $G 6 P C$ tended to show higher abundance pp than ap $(P<0.1)$ without group differences, but decreased strongly with insulin treatment at both time points $(P<0.001$; Figure 1D). The PCCA mRNA abundance was affected only by insulin treatment and decreased after the EGHIC $(P$ $<0.001$; Figure 1E). The SLC2A2 mRNA levels were affected only by time and decreased from ap to pp ( $P$ $<0.001$, Figure 2A). The SLC2A4 mRNA abundance decreased with time $(P<0.001$, Figure $2 \mathrm{~B})$, increased with insulin treatment $(P<0.001)$, and was higher in LLFC cows than in HLFC cows at both time points $(P$ $<0.01)$. In addition, $S L C 2 A 4 \mathrm{mRNA}$ was affected by block and run $(P<0.05$, Table 1$)$.

\section{Genes Related to Hepatic Lipid Metabolism}

The abundance of ACSL1 mRNA was unaffected in this study (Figure 3A; Table 1), whereas CPT1A mRNA abundance was reduced by insulin treatment $(P<0.01$, Figure 3B; Table 1). We observed no significant effects with regard to LFC or time for CPT1A mRNA abundances. The $A C A D V L \mathrm{mRNA}$ abundance increased from ap to pp similarly in both groups $(P<0.01$, Figure 3C; Table 1). After the EGHIC, the ACADVL mRNA abundance was reduced $(P=0.03)$ ap and pp. The mRNA abundance of $H M G C S 1$ increased from ap to pp $(P=0.03$; Figure 3D; Table 1$)$. The expression of $A C A D V L$ and $H M G C S 1 \mathrm{mRNA}$ were affected by run $(P<0.05)$. The abundance of HMGCS2 mRNA was not affected by LFC, insulin, or time (Figure 3E; Table 1). The abundance of $S R E B F 1 \mathrm{mRNA}$ was greater ap than pp $(P<0.01)$ and was affected by run $(P=0.05$; Figure $3 \mathrm{~F}$, Table 1$)$.

\section{Genes Related to the Somatotropic Axis and the Adrenergic and Glucocorticoid System}

The abundance of INSR mRNA was suppressed by insulin treatment $(P<0.001$, Figure 4A; Table 1$)$. The $I G F 1$ mRNA abundance decreased from ap to pp $(P<$
0.001, Figure 4B; Table 1), and the insulin treatment increased IGF1 mRNA more after than before calving $(P<0.001$; time $\times$ insulin interaction: $P=0.08)$. We observed an overall trend for a greater expression of IGF1 mRNA abundance in HLFC than LLFC $(P=$ 0.1 ; Figure 4B; Table 1). The mRNA abundance of the GHR1A decreased from ap to pp $(P=0.001$; Figure $4 \mathrm{C}$; Table 1), whereas after calving, insulin action led to increased GHR1A mRNA abundance in both groups but did not reach ap levels (time $\times$ insulin interaction: $P=0.01)$. In addition, we observed a trend $(P=0.1)$ for greater GHR1A mRNA abundance in HLFC cows than in LLFC cows. Run influenced the mRNA expression of $\operatorname{GHR} 1 A(P=0.05)$.

The abundance of $A D R A 1 A$ mRNA was lower after calving than before calving $(P=0.03$, Figure $5 \mathrm{~A})$, and HLFC cows tended to have lower ADRA1A mRNA abundance than LLFC cows pp but not ap (LFC $\times$ time interaction: $P=0.07$, Table 1). For $A D R B 2$ mRNA, abundance was not affected by LFC, time, or insulin treatment. The abundance of NR3C1 mRNA declined from ap to pp, especially in the HLFC cows, but decreased after insulin treatment pp only in the LLFC cows (time: $P=0.01 ;$ LFC $\times$ time $\times$ insulin interaction: $P=0.04$; Figure 5C). Furthermore, NR3C1 mRNA expression was influenced by block and run (Table 1).

\section{DISCUSSION}

\section{Gene Expression of Enzymes and Transporters Involved in Carbohydrate Metabolism}

Enzymes that regulate the main metabolic pathways of gluconeogenesis will be encoded by $P C, P C K 1$, $P C K 2, P C C A$, and $G 6 P C$ mRNA, and PC, PEPCK, and G6Pase catalyze the rate-limiting steps (KrausFriedmann, 1984). The gene expression of $P C, P C K 1$, and $G 6 P C$ (trend) increase from late pregnancy to early lactation, and these effects have also been observed by others (Greenfield et al., 2000; Loor, 2010; Weber et al., 2013a).

Insulin is the main endocrine agent that inhibits hepatic glucose production (Kraus-Friedmann, 1984; Pilkis and Granner, 1992). Insulin treatment clearly depressed the gene expression of $P C K 1$ and $G 6 P C$ before and after calving, whereas depression of $P C K 2 \mathrm{mRNA}$ was weak, and we measured no significant depression of $P C$ mRNA after insulin treatment. These findings contribute to our understanding of the inhibitory effect of insulin on endogenous glucose production in the liver but may also explain why endogenous glucose production is not completely blocked by insulin, as recently described for the cows in the present study (Weber et 

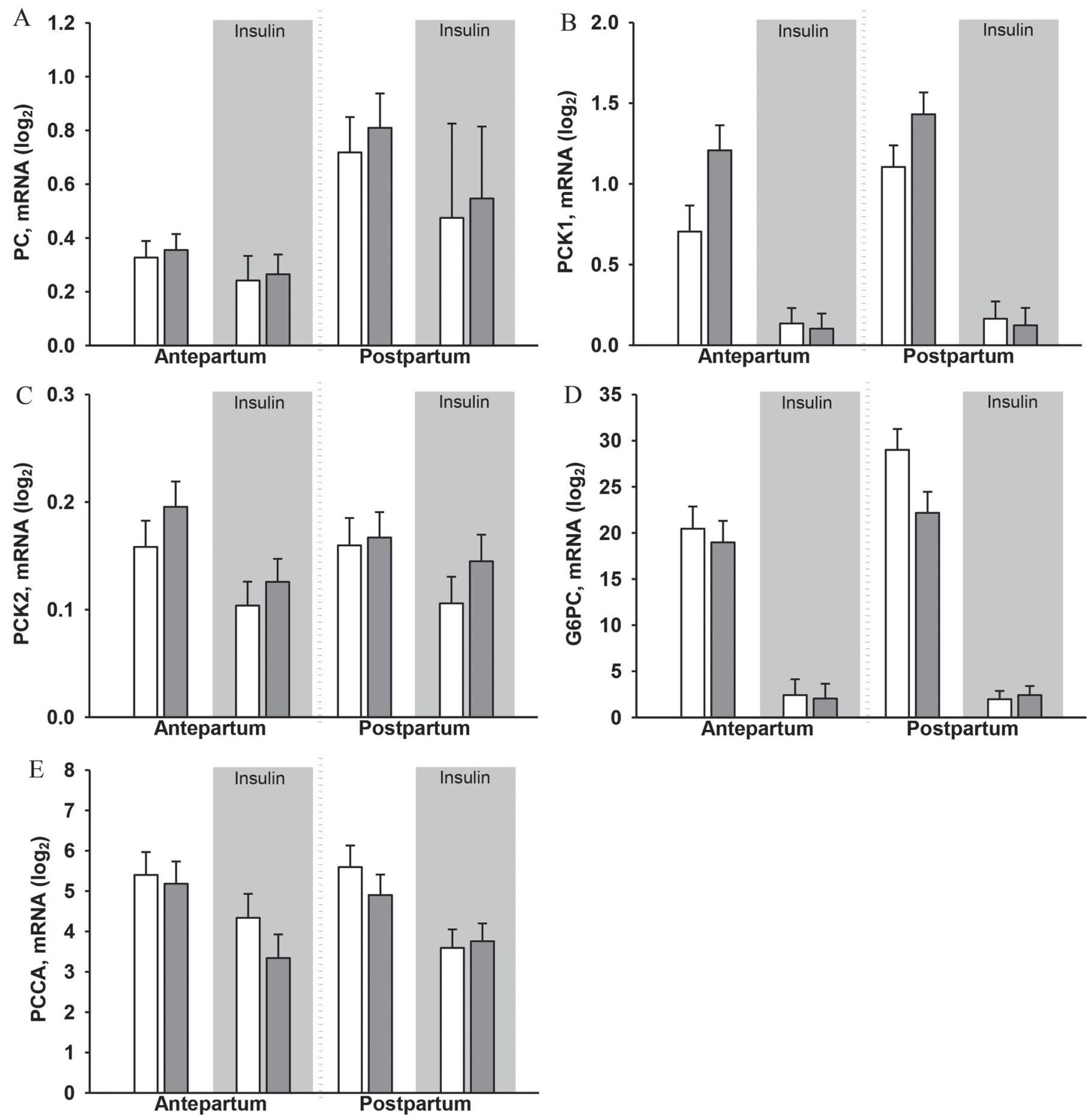

Figure 1. Relative mRNA expression $\left(\log _{2}\right)$ of pyruvate carboxylase $(P C ; \mathrm{A})$, cytosolic phosphoenolpyruvate carboxykinase $(P C K 1 ; \mathrm{B})$, mitochondrial phosphoenolpyruvate carboxykinase ( $P C K 2$; C), glucose-6-phosphatase $(G 6 P C$; D), and propionyl-CoA carboxylase $\alpha(P C C A$; E) in the livers of cows with low (white bars) and high (gray bars) liver fat concentration before and after insulin treatment at wk 5 antepartum and wk 3 postpartum. Values are LSM $\pm \mathrm{SE}$. Statistics ( $P$-values) are presented in Table 1.

al., 2016). The incomplete inhibition of endogenous glucose production by insulin is also known from studies in preruminant and ruminating calves (Hugi et al., 1998;
Scheuer et al., 2006). The reduced inhibitory effect of insulin treatment on $P C$ and $P C K 2$ gene expression may enable residual hepatic glucose production in the 
HEPATIC GENE EXPRESSION IN COWS

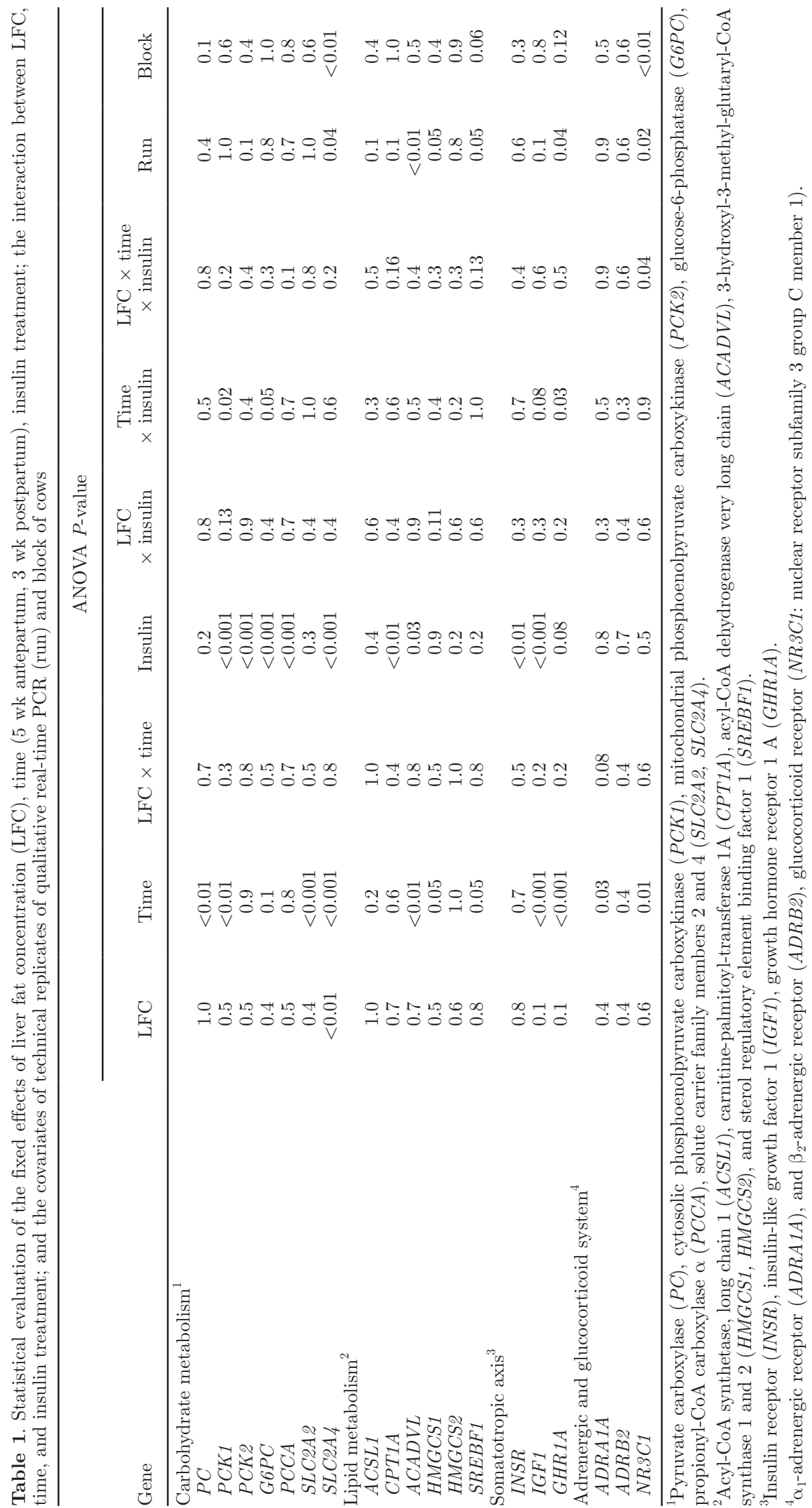



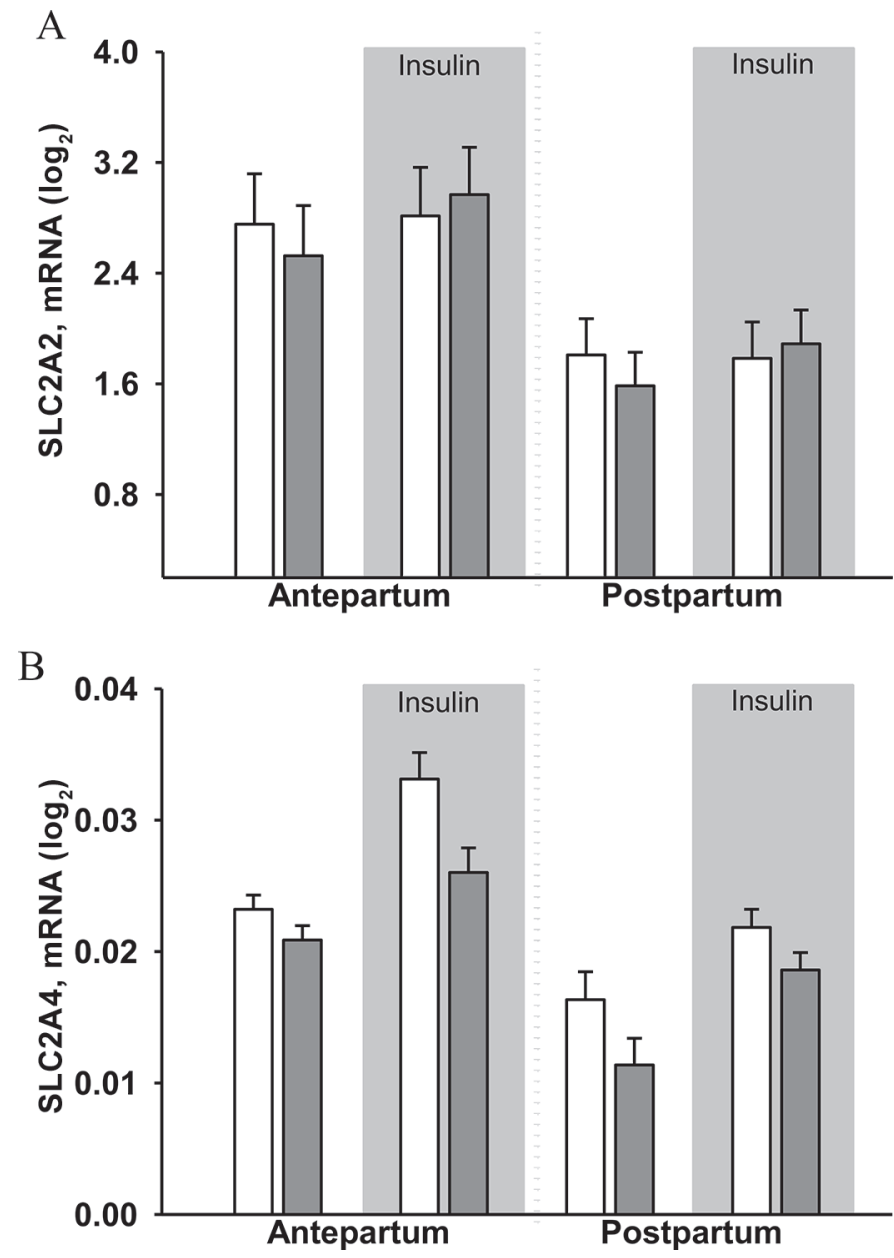

Figure 2. Relative mRNA expression $\left(\log _{2}\right)$ of solute carrier family 2 members 2 and 4 (SLC2A2, A; SLC2A 4, B) in the livers of cows with low (white bars) and high (gray bars) liver fat concentration before and after insulin treatment in wk 5 antepartum and wk 3 postpartum. Values are LSM \pm SE. Statistics ( $P$-values) are presented in Table 1.

liver, even when insulin is given at a supraphysiological dose (about 50- to 70-fold greater plasma concentrations than in the fed state), as in the present study (Weber et al., 2016). In adult monogastrics and humans, insulin treatment almost abolishes endogenous glucose production (Hulman and Kliegman, 1989; Farrag et al., 1997). In addition, we have observed a greater reduction of PCK1 and G6PC gene expression pp than ap, although hepatic insulin binding sites may have been reduced during early lactation, as seen for ewes (Gill and Hart, 1980). However, the insulin dose used in this study was supraphysiological and cannot be compared with insulin response using physiological insulin doses.

The same is true for the insulin response of $P C K 2$ gene expression in our study. The expression of the $P C K 2$ gene in the liver is less under diet and endocrine control than expression of PCK1 (Croniger et al.,
2002); the slight reduction observed in the present study might be a result of the supraphysiological insulin dose used in the present study. Current knowledge of PCK2 gene regulation does not suggest that insulin influences transcriptional inhibition (Beale et al., 2007; Stark et al., 2014). Studies on the response of PCK2 mRNA abundance indicate substrate regulation (Kreipe et al., 2011; Zhang et al., 2016), but no insulin effect. However, insulin inhibits PCK2 mRNA abundance after stimulation by propionate in the hepatocytes of neonatal calves (Zhang et al., 2016). A comparably slight but significant decrease was also seen for $P C C A$ gene expression after insulin treatment. Less is known about the transcriptional regulation of $P C C A$, but a close relation to phosphoenolpyruvate carboxykinase was recently assumed (Aschenbach et al., 2010).

In contrast to $P C K 2$, the gene expression of $P C K 1$ is strongly inhibited by insulin (Pilkis and Granner, 1992; Hanson and Reshef, 1997). The decrease of PCK1 mRNA abundance was even stronger pp than ap and mirrored the dominant inhibitory effect of insulin on PCK1 gene expression (Pilkis and Granner, 1992; Hanson and Reshef, 1997). Recent findings in hepatocytes of neonatal calves indicated an inhibitory effect of insulin on PCK1 mRNA abundance when PCK1 mRNA was stimulated with either propionate or cAMP and dexamethasone (Zhang et al., 2016). In mid-lactation dairy cows, insulin counteracts the stimulatory effect of propionate on PCK1 gene expression (Zhang et al., 2015). The gene expression of G6PC behaved comparably to PCK1 (van Schaftingen and Gerin, 2002; Desvergne et al., 2006), and clearly decreased after insulin treatment in the present study, with a greater effect pp. A significant inhibition of $G 6 P C$ mRNA abundance was also seen in mid-lactation dairy cows after insulin treatment (Kreipe et al., 2011).

Surprisingly, insulin treatment did not decrease $P C$ gene expression in a significant manner in the present study, although we used a supraphysiological insulin dose and insulin suppresses hepatic $P C$ gene expression in rats (Jitrapakdee and Wallace, 1999). However, insulin treatment in mid-lactation dairy cows did not indicate a significant effect on $P C$ gene expression (Kreipe et al., 2011). Insulin regulates the enzymes involved in hepatic gluconeogenesis via phosphorylation of cAMP response element (CREB)-binding protein (Zhou et al., 2004) and CREB binding sites have been identified in $P C K 1$ and $G 6 P C$ promoters but not in $P C$ promoters (Desvergne et al., 2006). The regulation of $P C$ mRNA abundance seems to be substrate-driven, and NEFA may stimulate hepatic PC gene expression by activating PC promoter 1 (White et al., 2011). The slight but nonsignificant decrease in $P C$ mRNA abundance after insulin treatment might be a consequence of the 

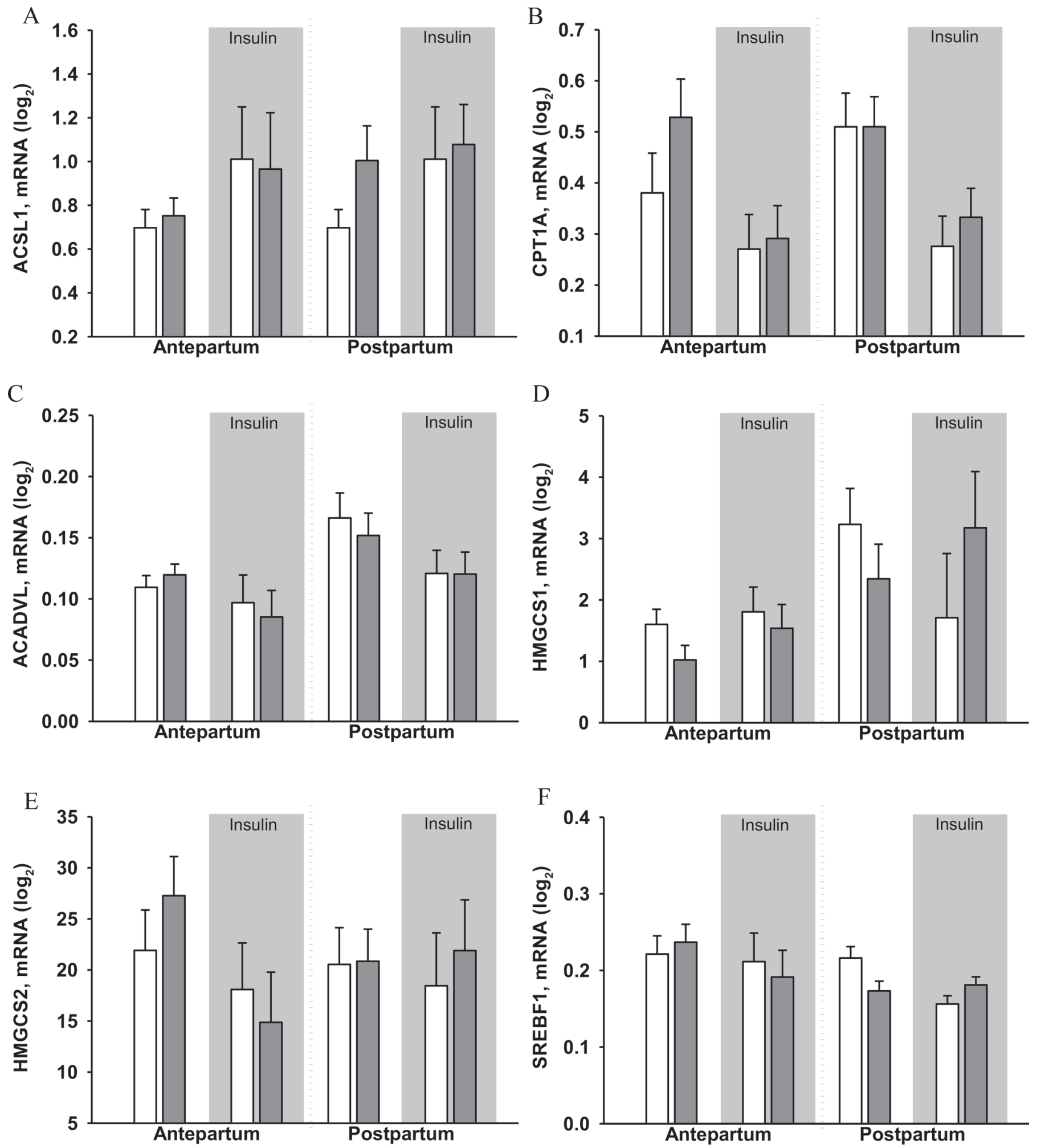

Figure 3. Relative mRNA expression ( $\left.\log _{2}\right)$ of acyl-CoA synthetase, long chain 1 (ACSL1; A), carnitine palmitoyl-transferase 1 A (CPT1A; B), acyl-CoA dehydrogenase very long chain (ACADVL; C), 3-hydroxyl-3-methyl-glutaryl-CoA synthase 1 (HMGCS1; D), 3-hydroxyl-3-methylglutaryl-CoA synthase 2 (HMGCS2; E), and sterol regulatory element binding factor 1 (SREBF1; F) in the livers of cows with low (white bars) and high (gray bars) liver fat concentration before and after insulin treatment in wk 5 antepartum and wk 3 postpartum. Values are LSM \pm SE. Statistics ( $P$-values) are presented in Table 1. 
A

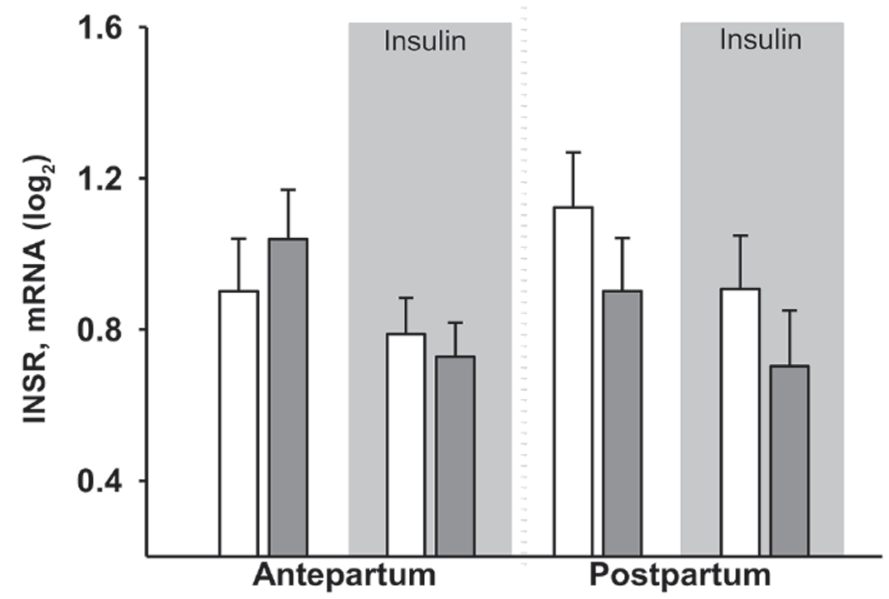

B

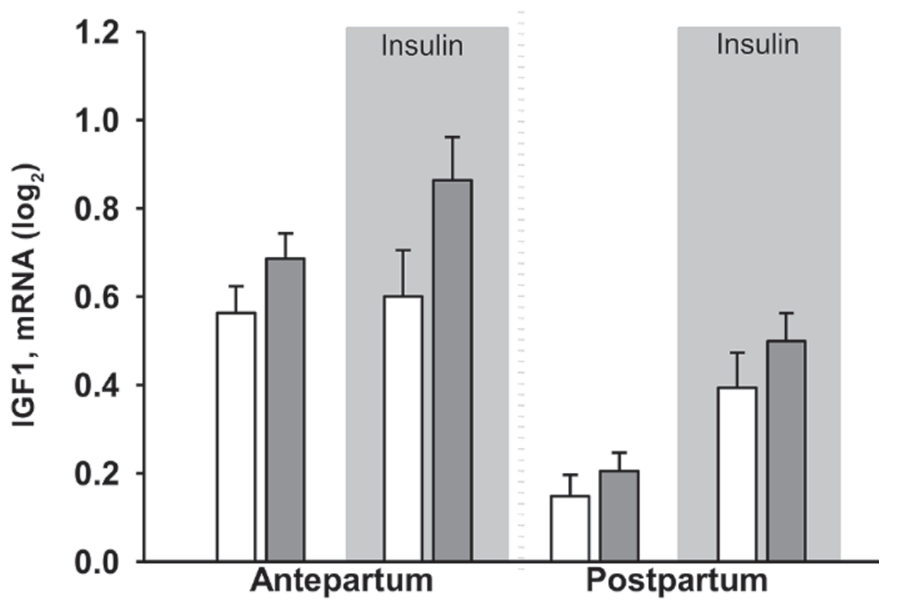

C

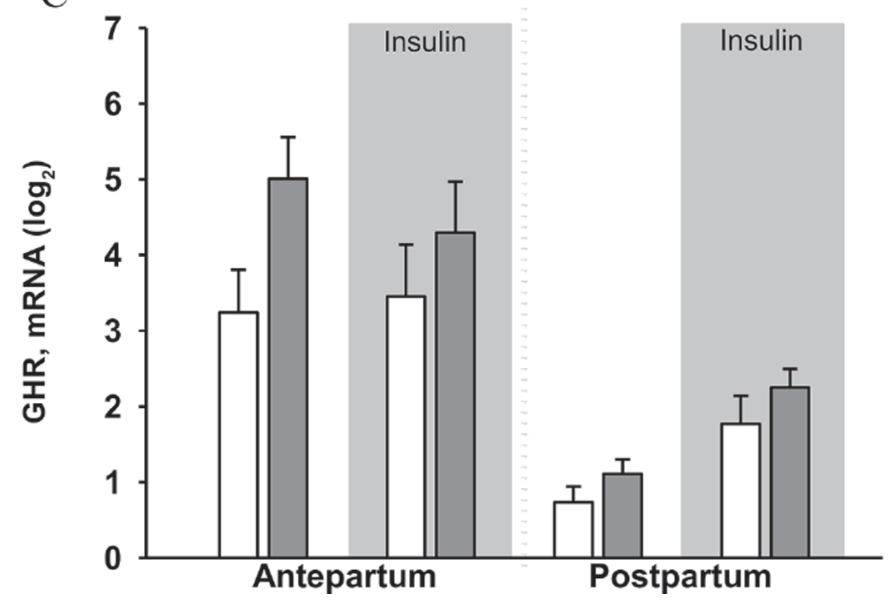

Figure 4. Relative mRNA expression $\left(\log _{2}\right)$ of insulin receptor (INSR; A), insulin-like growth factor 1 (IGF1; B), and growth hormone receptor 1A $($ GHR1A; $\mathrm{C})$ in the livers of cows with low (white bars) and high (gray bars) liver fat concentration before and after insulin treatment in wk 5 antepartum and wk 3 postpartum. Values are $\mathrm{LSM} \pm \mathrm{SE}$. Statistics ( $P$-values) are presented in Table 1.

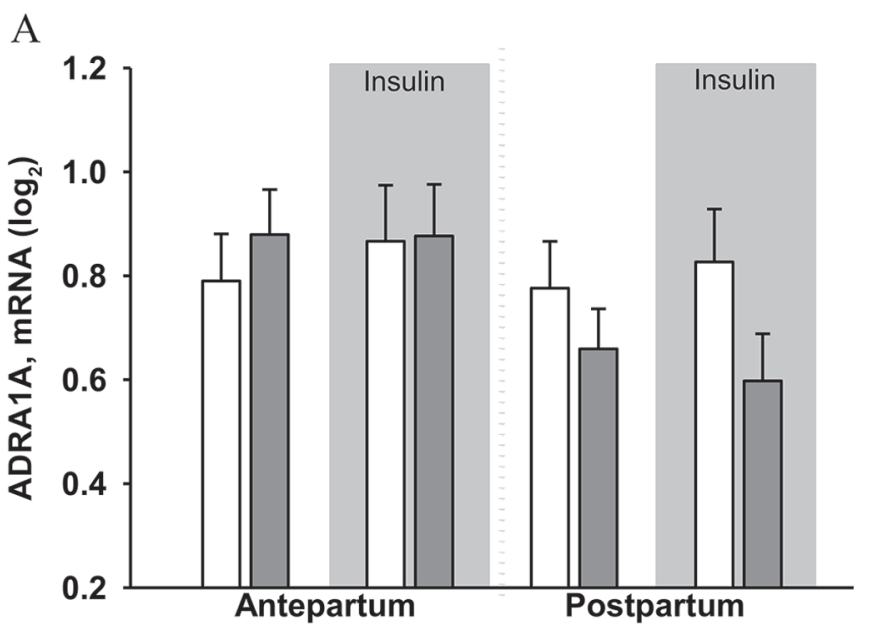

B

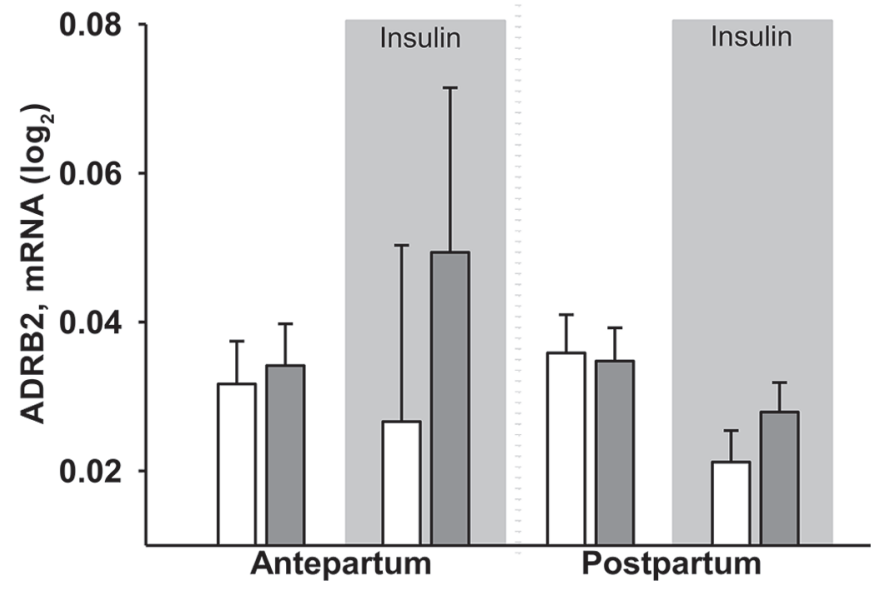

C

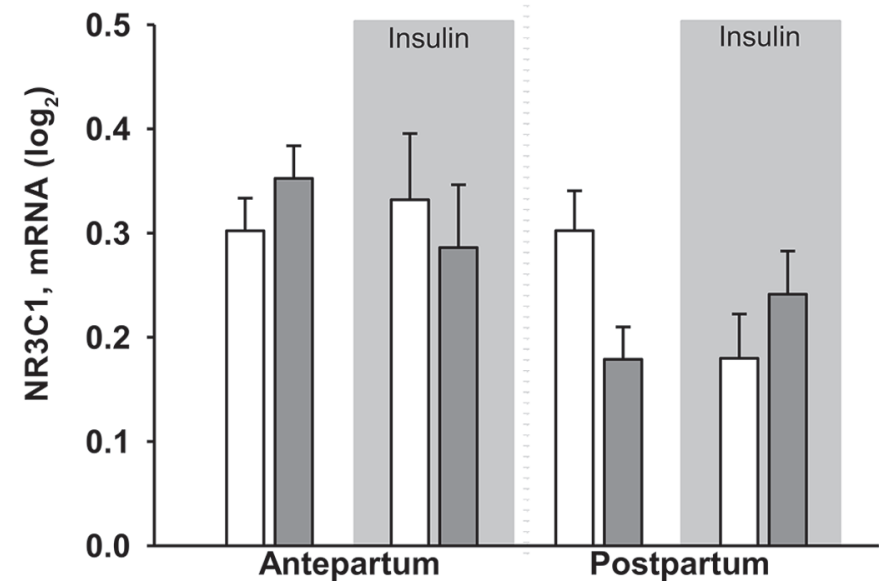

Figure 5. Relative mRNA expression $\left(\log _{2}\right)$ of adrenoceptor $\alpha 1 \mathrm{~A}$ $(A D R A 1 A ; \mathrm{A})$, adrenoceptor $\beta 2(A D R B 2 ; \mathrm{B})$, and nuclear receptor subfamily 3 group 3 member 1 (NR3C1; C) in the livers of cows with low (white bars) and high (gray bars) liver fat concentration before and after insulin treatment in wk 5 antepartum and wk 3 postpartum. Values are LSM $\pm \mathrm{SE}$. Statistics ( $P$-values) are presented in Table 1. 
reduced NEFA concentrations in the blood plasma due to the application of insulin in the cows.

The transmembrane transport of glucose is carried out predominantly by insulin-independent glucose transporter GLUT2, encoded by SLC2A2 mRNA. GLUT2 is most abundant in bovine hepatic tissue (Zhao et al., 1993), and in humans and mice, GLUT2 is the primary transporter that mediates glucose release from the hepatocytes (Thorens, 2015). The expression of SLC2A2 mRNA was reduced after calving in this study; however, hepatic glucose output after calving increases tremendously in dairy cows (Reynolds et al., 2003). Previous studies have not indicated time changes for SLC2A2 mRNA and GLUT2 protein expression with respect to calving (Hammon et al., 2009; Kinoshita et al., 2016).

We also detected a weak gene expression for SLC2A4, which encodes for the insulin-dependent glucose transporter GLUT4. This finding was surprising, because no gene expression has been reported so far in bovine liver (Zhao et al., 1993; Zhao and Keating, 2007). In addition, SLC2A4 gene expression decreased during the transition period, was stimulated after insulin treatment, and was greater in LLFC cows. These findings imply endocrine regulation as known from muscle tissue (Sasaki, 2002) and greater insulin response in lean cows as recently postulated by De Koster et al. (2015). However, due to the low mRNA abundance of SLC2A4 in the liver of these cows and the high insulin dose used in this study, the physiological relevance of these findings is questionable.

\section{Gene Expression of Hepatic Enzymes and Transcription Factors Involved in Lipid Metabolism}

Hepatic $\beta$-oxidation increases with the beginning of lactation in dairy cows (Drackley et al., 2001; Schäff et al., 2012). In our study, greater gene expression of $A C A D V L$ indicated greater hepatic $\beta$-oxidation pp. The supraphysiological insulin dose reduced the gene expression of $C P T 1 A$ and $A C A D V L$. It is not clear whether this was a direct effect of insulin on the expression of CPT1A and ACADVL. In rodents, insulin stimulates malonyl-CoA and shifts cytosolic acyl-CoA to esterification (Zammit, 1996; Nguyen et al., 2008). However, in ruminants, such an insulin effect is not shown, and with the supraphysiological insulin dose used in the present study, a physiological insulin response cannot be proven. Nevertheless, insulin seems to depress $\beta$-oxidation of long-chain fatty acids during early lactation (Andersen et al., 2002). Reduced plasma NEFA concentration after insulin treatment and, therefore, decreased hepatic NEFA concentration may also contribute to decreased gene expression of $C P T 1 A$ and $A C A D V L$, because hepatic $\beta$-oxidation depends on hepatic NEFA uptake (Nguyen et al., 2008). However, in vitro studies in calf hepatocytes clearly showed dosedependent inhibition of ACSL1, CPT1A, and ACADVL gene and protein expression by insulin, indicating insulin-dependent regulation of these enzymes at the transcriptional level (Li et al., 2013).

Gene expression of HMGCS2 is related to ketogenesis (Hegardt, 1999), but HMGCS2 mRNA abundance did not exhibit time, LFC, or insulin effects in the present study. As discussed above, the time points of liver sampling may have missed immediate changes of HMGCS2 around the time of calving, as indicated recently (van Dorland et al., 2009; Weber et al., 2013a). Gene expression of HMGCS1 is involved in cholesterol synthesis (Loor, 2010) and increased pp in the present study, supporting previous findings (van Dorland et al., 2009; Weber et al., 2013a).

The gene expression of SREBF1 was slightly higher before calving than after. The gene expression of $S R E B F 1$ codes for the sterol regulatory element binding protein 1, a transcription factor that is involved in the insulin-dependent regulation of lipogenesis and cholesterol synthesis in rodents, as well as in cattle (Nguyen et al., 2008; Viturro et al., 2009). The gene expression of SREBF1 has recently been shown to decrease at parturition to mimic reduced hepatic lipogenesis but to increase during early lactation (Graber et al., 2010; Loor, 2010; Weber et al., 2013a).

\section{Gene Expression of Factors Related to the Somatotropic Axis and the Adrenergic and Glucocorticoid System}

With the onset of milk production, cows undergo a negative energy balance that is linked to a decoupled somatotropic axis, indicated by elevated growth hormone but reduced IGF-1 and insulin in blood plasma (Ronge et al., 1988; Etherton and Bauman, 1998; Reist et al., 2003). In dairy cows, the decoupled somatotropic axis is the consequence of reduced gene expression of GHR1A and decreased growth hormone binding (e.g., in liver, leading to a decreased $I G F 1$ gene expression and plasma IGF-1 concentration; Kobayashi et al., 1999; Butler et al., 2003; Gross et al., 2011). Although we did not measure the plasma concentrations of growth hormone and IGF-1 in this study, reduced gene expression of GHR1A and IGF1 suggests a decoupling of the somatotropic axis after calving. The reduced gene expression of GHR1A and IGF1 is caused by impaired metabolic status (i.e., by reduced plasma glucose and insulin concentrations; McGuire et al., 1995; Brameld et al., 1999; Breier, 1999), and impaired insulin status 
has been observed in dairy cows at the beginning of lactation (Reist et al., 2003; De Koster and Opsomer, 2013; Weber et al., 2013b), as well as in the cows of this study (Weber et al., 2016).

Consequently, elevated insulin status removes the decoupling of the somatotropic axis, indicated by an increase of GHR1A and IGF1 gene expression and a decreased growth hormone /IGF-1 ratio in blood plasma (Butler et al., 2003). Accordingly, the gene expression of GHR1A and IGF1 increased after the EGHIC in our study. Interestingly, GHR1A and IGF1 mRNA abundance was slightly higher in HLFC cows than in LLFC cows. However, whether hepatic growth hormone binding depends on the metabolic type of the cow is not known yet and requires further investigation. The gene expression of INSR was depressed by the supraphysiological insulin dose. In mid-lactation dairy cows, insulin treatment by EGHIC did not affect INSR mRNA abundance in the liver (Kreipe et al., 2011). However, calf hepatocytes treated with insulin showed decreased INSR mRNA abundance in a dose-dependent manner (Zhang et al., 2011). We do not know whether the high insulin dose used in this study affected hepatic insulin binding.

Glucocorticoids and catecholamines are important regulators of energy partitioning, and they affect hepatic glucose and lipid metabolism in ruminants (Mc Dowell, 1983; Brockman and Laarveld, 1986). In the liver, adrenaline and noradrenaline bind to their specific receptors (e.g., $\alpha_{1}$-adrenergic receptor and $\beta_{2}$-adrenergic receptor; Schmelck and Hanoune, 1980; Sulakhe et al., 1988), and cortisol binds to the glucocorticoid receptor (Vegiopoulos and Herzig, 2007). Gene expression of $A D R A 1 A$ and NR3C1 decreased after calving, and for both receptors, the decrease was higher in HLFC cows than in LLFC cows. Previous findings in dairy cows have indicated a relation between the $\alpha_{1}$-adrenergic binding sites and substrate oxidation in dairy cows, supporting the importance of the hepatic $\alpha_{1}$-adrenergic system for the regulation of energy metabolism (Goodhardt et al., 1984; Hammon et al., 2013). In addition, the glucocorticoid system is involved in the regulation of hepatic energy metabolism (Pilkis and Granner, 1992; Vegiopoulos and Herzig, 2007). Therefore, both systems may play an important role in the regulation of energy metabolism during the transition period in dairy cows.

\section{CONCLUSIONS}

Gene expression related to hepatic energy metabolism and the regulation of energy partitioning is less affected by the metabolic type of cows (LLFC vs. HLFC) but partly indicates well-known changes during the transi- tion from pregnancy to lactation and responds to insulin treatment before and after calving. Insulin inhibits hepatic glucose production and $\beta$-oxidation in dairy cows during the transition period. Although we used a supraphysiological dose of insulin in this study and results must be interpreted with caution, our results indicate variable insulin effects on the degree of depression of individual genes with respect to carbohydrate metabolism. Insulin status is important for the regulation of nutrient partitioning through the somatotropic axis, but insulin does not affect the adrenergic and glucocorticoid receptors at the transcriptional level.

\section{ACKNOWLEDGMENTS}

We thank Anne-Kathrin Möller, the staff at the Experimental Cattle Facility of the FBN (Bernd Stabenow and co-workers), and the animal caretakers (Dirk Oswald, Roland Gaeth, Astrid Schulz, Kerstin Pilz, and Kerstin Korinth) of the Institute of Nutritional Physiology for help with biochemical analyses and animal care. We further acknowledge the help of the Cattle Breeding Organization Mecklenburg-West Pomerania (Rinderallianz, Woldegk, Germany) and the Griepentrog Farm (Steinhagen, Germany) for the assortment of cows. This study was supported by Deutsche Forschungsgemeinschaft (DFG; Bonn, Germany; HA 4372/7-1).

\section{REFERENCES}

Andersen, J. B., D. G. Mashek, T. Larsen, M. O. Nielsen, and K. L. Ingvartsen. 2002. Effects of hyperinsulinaemia under euglycaemic condition on liver fat metabolism in dairy cows in early and midlactation. J. Vet. Med. A Physiol. Pathol. Clin. Med. 49:65-71.

Aschenbach, J. R., N. B. Kristensen, S. S. Donkin, H. M. Hammon, and G. B. Penner. 2010. Gluconeogenesis in dairy cows: The secret of making sweet milk from sour dough. IUBMB Life 62:869-877.

Bauman, D. E. 2000. Regulation of nutrient partitioning during lactation: Homeostasis and homeorhesis revisited. Pages 311-328 in Ruminant Physiology: Digestion, Metabolism, Growth and Reproduction. P. B. Cronje, ed. CAB International, Wallingford, UK.

Beale, E. G., B. J. Harvey, and C. Forest. 2007. PCK1 and PCK2 as candidate diabetes and obesity genes. Cell Biochem. Biophys. 48:89-95.

Börner, S., E. Albrecht, C. Schaff, S. Hacke, U. Kautzsch, M. Derno, H. M. Hammon, M. Rontgen, H. Sauerwein, and B. Kuhla. 2013. Reduced AgRP activation in the hypothalamus of cows with high extent of fat mobilization after parturition. Gen. Comp. Endocrinol. 193:167-177.

Brameld, J. M., R. S. Gilmour, and P. J. Buttery. 1999. Glucose and amino acids interact with hormones to control expression of insulin-like growth factor-I and growth hormone receptor mRNA in cultured pig hepatocytes. J. Nutr. 129:1298-1306.

Breier, B. H. 1999. Regulation of protein and energy metabolism by the somatotropic axis. Domest. Anim. Endocrinol. 17:209-218.

Brockman, R. P., and B. Laarveld. 1986. Hormonal regulation of metabolism in ruminants; a review. Livest. Prod. Sci. 14:313-334.

Butler, S. T., A. L. Marr, S. H. Pelton, R. P. Radcliff, M. C. Lucy, and W. R. Butler. 2003. Insulin restores GH responsiveness during lactation-induced negative energy balance in dairy cattle: Effects on expression of IGF-I and GH receptor 1A. J. Endocrinol. 176:205-217. 
Croniger, C. M., Y. Olswang, L. Reshef, S. C. Kalhan, S. M. Tilghman, and R. W. Hanson. 2002. Phosphoenolpyruvate carboxykinase revisited: Insights into its metabolic role. Biochem. Mol. Biol. Educ. 30:14-20.

De Koster, J., M. Hostens, M. Van Eetvelde, K. Hermans, S. Moerman, H. Bogaert, E. Depreester, W. Van den Broeck, and G. Opsomer. 2015. Insulin response of the glucose and fatty acid metabolism in dry dairy cows across a range of body condition scores. J. Dairy Sci. 98:4580-4592.

De Koster, J. D., and G. Opsomer. 2013. Insulin resistance in dairy cows. Vet. Clin. North Am. Food Anim. Pract. 29:299-322.

Desvergne, B., L. Michalik, and W. Wahli. 2006. Transcriptional regulation of metabolism. Physiol. Rev. 86:465-514.

Donkin, S. S. 1999. Role of the endocrine pancreas in animal metabolism, growth and performance. Pages 315-328 in Biology of the Pancreas in Growing Animals. S. G. Pierzynowski and R. Zabielski, ed. Elsevier, Amsterdam, the Netherlands.

Drackley, J. K., T. R. Overton, and G. N. Douglas. 2001. Adaptations of glucose and long-chain fatty acid metabolism in liver of dairy cows during the periparturient period. J. Dairy Sci. 84(E. Suppl.):E100-E112.

Etherton, T. D., and D. E. Bauman. 1998. Biology of somatotropin in growth and lactation of domestic animals. Physiol. Rev. 78:745761.

Farrag, H. M., L. M. Nawrath, J. E. Healey, E. J. Dorcus, R. E. Rapoza, W. Oh, and R. M. Cowett. 1997. Persistent glucose production and greater peripheral sensitivity to insulin in the neonate vs. the adult. Am. J. Physiol. 272:E86-E93.

GfE (German Society of Nutrition Physiology). 2001. Empfehlungen zur Energie- und Nährstoffversorgung der Milchkühe und Aufzuchtrinder [Recommended energy and nutrient supply for dairy cows and heifers]. Ausschuss für Bedarfsnormen der Gesellschaft für Ernährungsphysiologie No. 8. DLG Verlag, Frankfurt am Main, Germany.

GfE (German Society of Nutrition Physiology). 2008. New equations for predicting metabolisable energy of grass and maize products for ruminants. Mitteilung des Ausschusses für Bedarfsnormen der Gesellschaft für Ernährungsphysiologie. Proc. Soc. Nutr. Physiol. 17:191-198.

Gill, R. D., and I. C. Hart. 1980. Properties of insulin and glucagon receptors on sheep hepatocytes: A comparison of hormone binding and plasma hormones and metabolites in lactating and nonlactating ewes. J. Endocrinol. 84:237-247.

Goodhardt, M., N. Ferry, M. Aggerbeck, and J. Hanoune. 1984. The hepatic alpha1-adrenergic receptor. Biochem. Pharmacol. 33:863868.

Graber, M., S. Kohler, T. Kaufmann, M. G. Doherr, R. M. Bruckmaier, and H. A. van Dorland. 2010. A field study on characteristics and diversity of gene expression in the liver of dairy cows during the transition period. J. Dairy Sci. 93:5200-5215.

Greenfield, R. B., M. J. Cecava, and S. S. Donkin. 2000. Changes in mRNA expression for gluconeogenic enzymes in liver of dairy cattle during the transition to lactation. J. Dairy Sci. 83:1228-1236.

Gross, J., H. A. van Dorland, F. J. Schwarz, and R. M. Bruckmaier. 2011. Endocrine changes and liver mRNA abundance of somatotropic axis and insulin system constituents during negative energy balance at different stages of lactation in dairy cows. J. Dairy Sci. 94:3484-3494.

Hammon, H. M., U. Kautzsch, C. Reiko, B. Kuhla, M. Röntgen, M. Derno, and C. C. Metges. 2013. Hepatic $\alpha 1$ - and $\beta 2$-adrenergic receptors in dairy cows with different fat mobilization during early lactation. Pages 275-276 in Energy and Protein Metabolism and Nutrition in Sustainable Animal Production. J.W. Oltjen, E. Kebreab, and H. Lapierre, ed. EAAP, No. 134, Wageningen Academic, Wageningen, the Netherlands.

Hammon, H. M., S. N. Sauter, M. Reist, Y. Zbinden, C. Philipona, C. Morel, and J. W. Blum. 2003. Dexamethasone and colostrum feeding affect hepatic gluconeogenic enzymes differently in neonatal calves. J. Anim. Sci. 81:3095-3106.
Hammon, H. M., G. Stürmer, F. Schneider, A. Tuchscherer, H. Blum, T. Engelhard, A. Genzel, R. Staufenbiel, and W. Kanitz. 2009. Performance and metabolic and endocrine changes with emphasis on glucose metabolism in high-yielding dairy cows with high and low fat content in liver after calving. J. Dairy Sci. 92:1554-1566.

Hanson, R. W., and L. Reshef. 1997. Regulation of phosphoenolpyruvate carboxykinase (GTP) gene expression. Annu. Rev. Biochem. $66: 581-611$.

Hayirli, A. 2006. The role of exogenous insulin in the complex of hepatic lipidosis and ketosis associated with insulin resistance phenomenon in postpartum dairy cattle. Vet. Res. Commun. 30:749-774.

Hegardt, F. G. 1999. Mitochondrial 3-hydroxy-3-methylglutaryl-CoA synthase: A control enzyme in ketogenesis. Biochem. J. 338:569 582.

Hugi, D., L. Tappy, H. Sauerwein, R. M. Bruckmaier, and J. W. Blum. 1998. Insulin-dependent glucose utilization in intensively milk-fed veal calves is modulated by supplemental lactose in an age-dependent manner. J. Nutr. 128:1023-1030.

Hulman, S. E., and R. M. Kliegman. 1989. Assessment of insulin resistance in newborn beagles with the euglycemic hyperinsulinemic clamp. Pediatr. Res. 25:219-223.

Ingvartsen, K. L., and J. B. Andersen. 2000. Integration of metabolism and intake regulation: A review focusing on periparturient animals. J. Dairy Sci. 83:1573-1597.

Jitrapakdee, S., and J. C. Wallace. 1999. Structure, function and regulation of pyruvate carboxylase. Biochem. J. 340:1-16.

Kinoshita, A., A. Kenez, L. Locher, U. Meyer, S. Danicke, J. Rehage, and K. Huber. 2016. Insulin signaling in liver and adipose tissues in periparturient dairy cows supplemented with dietary nicotinic acid. PLoS One 11:e0147028.

Kobayashi, Y., C. K. Boyd, C. J. Bracken, W. R. Lamberson, D. H Keisler, and M. C. Lucy. 1999. Reduced growth hormone receptor (GHR) messenger RNA in liver of periparturient cattle is caused by a specific down-regulation of GHR 1A that is associated with decreased insulin-like growth factor-I. Endocrinology 140:39473954 .

Kraus-Friedmann, N. 1984. Hormonal regulation of hepatic gluconeogenesis. Physiol. Rev. 64:170-259.

Kreipe, L., M. C. M. B. Vernay, A. Oppliger, O. Wellnitz, R. M. Bruckmaier, and H. A. van Dorland. 2011. Induced hypoglycemia for 48 hours indicates differential glucose and insulin effects on liver metabolism in dairy cows. J. Dairy Sci. 94:5435-5448.

Li, P., C. C. Wu, M. Long, Y. Zhang, X. B. Li, J. B. He, Z. Wang, and G. W. Liu. 2013. High insulin concentrations inhibit fatty acid oxidation-related gene expression in calf hepatocytes cultured in vitro. J. Dairy Sci. 96:3840-3844.

Loor, J. J. 2010. Genomics of metabolic adaptations in the peripartal cow. Animal 4:1110-1139.

McDowell, G. H. 1983. Hormonal control of glucose homoeostasis in ruminants. Proc. Nutr. Soc. 42:149-167.

McGuire, M. A., D. A. Dwyer, R. J. Harrell, and D. E. Bauman. 1995. Insulin regulates circulating insulin-like growth factors and some of their binding proteins in lactating cows. Am. J. Physiol. 269:E723-E730.

Nguyen, P., V. Leray, M. Diez, S. Serisier, J. Le Bloc'h, B. Siliart, and H. Dumon. 2008. Liver lipid metabolism. J. Anim. Physiol. Anim. Nutr. (Berl.) 92:272-283.

Pfaffl, M. W. 2001. A new mathematical model for relative quantification in real-time RT-PCR. Nucleic Acids Res. 29:e45.

Pilkis, S. J., and D. K. Granner. 1992. Molecular physiology of the regulation of hepatic gluconeogenesis and glycolysis. Annu. Rev. Physiol. 54:885-909.

Reist, M., D. Erdin, D. von Euw, K. Tschuemperlin, H. Leuenberger, C. Delavaud, Y. Chilliard, H. M. Hammon, N. Kuenzi, and J. W. Blum. 2003. Concentrate feeding strategy in lactating dairy cows: Metabolic and endocrine changes with emphasis on leptin. J. Dairy Sci. 86:1690-1706.

Reynolds, C. K., P. C. Aikman, B. Lupoli, D. J. Humphries, and D. E. Beever. 2003. Splanchnic metabolism of dairy cows during the 
transition from late gestation through early lactation. J. Dairy Sci. $86: 1201-1217$.

Ronge, H., J. Blum, C. Clement, F. Jans, H. Leuenberger, and H. Binder. 1988. Somatomedin C in dairy cows related to energy and protein supply and to milk production. Anim. Prod. 47:165-183.

Sano, H., S. Narahara, T. Kondo, A. Takahashi, and Y. Terashima. 1993. Insulin responsiveness to glucose and tissue responsiveness to insulin during lactation in dairy-cows. Domest. Anim. Endocrinol. 10:191-197.

SAS Institute. 2013. SAS/STAT 0.1 User's Guide. SAS Institute Inc., Cary, NC.

Sasaki, S. 2002. Mechanism of insulin action on glucose metabolism in ruminants. Anim. Sci. J. 73:423-433.

Schäff, C., S. Börner, S. Hacke, U. Kautzsch, D. Albrecht, H. M. Hammon, M. Röntgen, and B. Kuhla. 2012. Increased anaplerosis, TCA cycling, and oxidative phosphorylation in the liver of dairy cows with intensive body fat mobilization during early lactation. J. Proteome Res. 11:5503-5514.

Schäff, C. T., D. Rohrbeck, J. Steinhoff-Wagner, E. Kanitz, H. Sauerwein, R. M. Bruckmaier, and H. M. Hammon. 2014. Effects of colostrum versus formula feeding on hepatic glucocorticoid and alpha(1)- and beta(2)-adrenergic receptors in neonatal calves and their effect on glucose and lipid metabolism. J. Dairy Sci. 97:63446357.

Scheuer, B. H., Y. Zbinden, P. Schneiter, L. Tappy, J. W. Blum, and H. M. Hammon. 2006. Effects of colostrum feeding and glucocorticoid administration on insulin-dependent glucose metabolism in neonatal calves. Domest. Anim. Endocrinol. 31:227-245.

Schmelck, P.-H., and J. Hanoune. 1980. The hepatic adrenergic receptors. Mol. Cell. Biochem. 33:35-48.

Stark, R., F. Guebre-Egziabher, X. Zhao, C. Feriod, J. Dong, T. C. Alves, S. Ioja, R. L. Pongratz, S. Bhanot, M. Roden, G. W. Cline, G. I. Shulman, and R. G. Kibbey. 2014. A role for mitochondrial phosphoenolpyruvate carboxykinase (PEPCK-M) in the regulation of hepatic gluconeogenesis. J. Biol. Chem. 289:7257-7263.

Sulakhe, S. J., V. B. Pulga, and S. Tran. 1988. Hepatic $\alpha 1$ and $\beta$ adrenergic receptors in various animal species. Mol. Cell. Biochem. 83:81-88.

Thaller, G., C. Kühn, A. Winter, G. Ewald, O. Bellmann, J. Wegner, H. Zuhlke, and R. Fries. 2003. DGAT1, a new positional and functional candidate gene for intramuscular fat deposition in cattle. Anim. Genet. 34:354-357.

Thorens, B. 2015. GLUT2, glucose sensing and glucose homeostasis. Diabetologia 58:221-232.

van Dorland, H. A., S. Richter, I. Morel, M. G. Doherr, N. Castro, and R. M. Bruckmaier. 2009. Variation in hepatic regulation of metabolism during the dry period and in early lactation in dairy cows. J. Dairy Sci. 92:1924-1940.

van Schaftingen, E., and I. Gerin. 2002. The glucose-6-phosphatase system. Biochem. J. 362:513-532.
Vegiopoulos, A., and S. Herzig. 2007. Glucocorticoids, metabolism and metabolic diseases. Mol. Cell. Endocrinol. 275:43-61.

Viturro, E., M. Koenning, A. Kroemer, G. Schlamberger, S. Wiedemann, M. Kaske, and H. H. D. Meyer. 2009. Cholesterol synthesis in the lactating cow: Induced expression of candidate genes. J. Steroid Biochem. Mol. Biol. 115:62-67.

Weber, C., C. Hametner, A. Tuchscherer, B. Losand, E. Kanitz, W. Otten, H. Sauerwein, R. M. Bruckmaier, F. Becker, W. Kanitz, and H. M. Hammon. 2013a. Hepatic gene expression involved in glucose and lipid metabolism in transition cows: Effects of fat mobilization during early lactation in relation to milk performance and metabolic changes. J. Dairy Sci. 96:5670-5681.

Weber, C., C. Hametner, A. Tuchscherer, B. Losand, E. Kanitz, W Otten, S. P. Singh, R. M. Bruckmaier, F. Becker, W. Kanitz, and H. M. Hammon. 2013b. Variation in fat mobilization during early lactation differently affects feed intake, body condition, and lipid and glucose metabolism in high-yielding dairy cows. J. Dairy Sci. 96:165-180.

Weber, C., C. T. Schäff, U. Kautzsch, S. Börner, S. Erdmann, S. Görs, M. Röntgen, H. Sauerwein, R. M. Bruckmaier, C. C. Metges, B. Kuhla, and H. M. Hammon. 2016. Insulin-dependent glucose metabolism in dairy cows with variable fat mobilization around calving. J. Dairy Sci. 99:6665-6679.

White, H. M., S. L. Koser, and S. S. Donkin. 2011. Characterization of bovine pyruvate carboxylase promoter 1 responsiveness to serum from control and feed-restricted cows. J. Anim. Sci. 89:1763-1768.

Zammit, V. A. 1996. Role of insulin in hepatic fatty acid partitioning: Emerging concepts. Biochem. J. 314:1-14.

Zhang, Q., S. L. Koser, B. J. Bequette, and S. S. Donkin. 2015. Effect of propionate on mRNA expression of key genes for gluconeogenesis in liver of dairy cattle. J. Dairy Sci. 98:8698-8709.

Zhang, Q., S. L. Koser, and S. S. Donkin. 2016. Propionate induces mRNA expression of gluconeogenic genes in bovine calf hepatocytes. J. Dairy Sci. 99:3908-3915.

Zhang, Z., X. B. Li, G. W. Liu, L. Gao, C. M. Guo, T. Kong, H. B. Wang, R. F. Gao, Z. Wang, and X. L. Zhu. 2011. High insulin concentrations repress insulin receptor gene expression in calf hepatocytes cultured in vitro. Cell. Physiol. Biochem. 27:637-640.

Zhao, F. Q., D. R. Glimm, and J. J. Kennelly. 1993. Distribution of mammalian facilitative glucose-transporter messenger-RNA in bovine-tissues. Int. J. Biochem. 25:1897-1903.

Zhao, F. Q., and A. F. Keating. 2007. Functional properties and genomics of glucose transporters. Curr. Genomics 8:113-128.

Zhou, X. Y., N. Shibusawa, K. Naik, D. Porras, K. Temple, H. Ou, K. Kaihara, M. W. Roe, M. J. Brady, and F. E. Wondisford. 2004 Insulin regulation of hepatic gluconeogenesis through phosphorylation of CREB-binding protein. Nat. Med. 10:633-637. 